\title{
UTILIZATION EOS PLATFORM AS CLOUD-BASED GIS TO ANALYZE VEGETATION GREENNESS IN CIREBON REGENCY, INDONESIA
}

\author{
Moh. Dede ${ }^{1}$, Millary Agung Widiawaty ${ }^{2}$ \\ ${ }^{1}$ Master Program on Environmental Science, Postgraduate School, Universitas Padjadjaran, Bandung, Indonesia \\ ${ }^{2}$ Department of Geography Education, FPIPS, Universitas Pendidikan Indonesia, Bandung, Indonesia. \\ m.dede.geo@gmail.com
}

\begin{abstract}
Cloud-Based GIS development has been increasing rapidly since the need for big computing for online spatial data. Besides Google Earth Engine, there is another cloud-based GIS with similar features namely the EOS Platform. This study aims to analyze vegetation greenness in Cirebon Regency, Indonesia using the EOS Platform. The selection of research locations based on the rapid development in the Cirebon Regency. Vegetation greenness analysis using the NDVI algorithm which available on EOS Processing and Landsat series images are obtained from Land Viewer. Changes in vegetation greenness were analyzed descriptively from NDVI values in 1999 and 2019 at each pixel in the same location. The results of the analysis with the EOS Platform shows a decreasing vegetation greenness in the western and peri-urban areas caused by land use and land cover (LULC) changes. It is proven that the EOS Platform can be used for effective and efficient satellite image processing. Even so, some EOS Platform products with BETA version status still show some bugs related to integration between Land Viewer and EOS Storage
\end{abstract}

Keywords: Cirebon, EOS platform, remote sensing, vegetation greenness.

\section{INTRODUCTION}

Nowadays, advances in remote sensing technology require fast and accurate data processing. Conventional digital image processing based on personal computers (PCs) is processes of data acquisition, preprocessing, processing, post-processing, and interpretation from users as input in decision making $[1,2]$. The presence of many high-resolution satellite imageries which able to reach almost all the world such as Landsat series and Sentinel series causes demands to process image data was increasing [3,4]. Large data size, satellite multi-sensor and multispectral have an impact on offline computing which needs high specification of PCs and expensive to procure. On the other hand, development challenges for developing countries continue to increase and require adequate environmental monitoring but are constrained by computing infrastructure [5]. This phenomenon was responded by several institutions through the launch of cloud computing-based digital image processing platforms such as Google Earth Engine (Alphabet Limited), Landsat Cloud (USGS), Copernicus Hub (ESA), and EOS Platform (EOS Limited) [6]. This platform empowers computer systems from providers, thereby ensuring effective and efficient digital image processing.
In online platforms, users can use much coding software on PCs such as Jupyter Notebook, Conda, and R-Studio but to access digital satellite imagery requires credentials and application programming interface (API) from the service providers [7]. Cloud computing applications and services for image processing are considered efficient because they can cut data usages, computer resources, and time [8]. This process can also be done without having to download and install a digital image processing application that is generally large and paid, as long as there are an adequate connection and browser available. Another advantage of cloud computing-based image processing is the availability of datasets in the form of single access, thus users do not need to access the entire provider page to get the data [9]. Data analysis results that are usually smaller than the original data from providers can be downloaded faster and can be directly layout in geographic information system software (GIS) because it only downloads post-processing data.

Cloud computing platforms for digital image processing can save data usage; they enable users around the world to access super-computers that can process big earth data [10]. The cloud computing platform also saves electricity usage and does not force excessive use of computer hardware resulting in damage. Even so, the digital image processing platforms based on cloud computing relatively is not without obstacles. The obstacles manifestation is the platform operation which is mostly text-based which requires programming skills in some languages such as PHP, Python, and R [11]. Thus, are all digital image processing platforms based on cloud computing like that? EOS appears to address these obstacles through the EOS Platform as a Cloud-Based GIS that presents a graphical user interface (GUI) [12]. This platform provides access to many satellite image data providers and algorithms to process them. In appearance, the outputs of the EOS Platform and Google Earth Engine are almost similar because each provides a split image feature and diverse base maps. Besides, the EOS Platform has another advantage because it has an image mosaic feature directly on the data selection menu.

In contrast to previous studies that the majority used Google Earth Engine which began in 2010 [13], this study offers an alternative; testing the effectiveness and efficiency of the EOS Platform as a cloud-based GIS. Therefore, this study aims to analyze the vegetation greenness in Cirebon Regency 
using the EOS Platform. The Normalized Difference Vegetation Index (NDVI) algorithm chosen based on the phenomenon of LULC changes in many sub-districts and has a significant relationship between vegetation greenness and air temperature increasing [14]. Besides, the dataset for vegetation greenness is available from many sources such as USGS, ESA, NASA, and NOAA, it can be used for validation and further analysis. This research is also expected to be an example in the analysis of vegetation greenness based on a cloud-based GIS platform approach.

\section{METHOD}

\section{A. Tools and Materials}

This research took an area of interest (AOI) of an administrative region namely Cirebon Regency, West Java, Indonesia. Boundary data were obtained from PODES compiled by the Indonesian Statistics Agency (BPS). The vector data of Cirebon Regency which were originally in the form of Shapefile (*shp) must be changed to Keyhole Markup Language $(* \mathrm{kml})$ or Zipper KML $(* \mathrm{kmz})$. This conversion aims to adjust the data types that can be supported by the browser and has tag structures with names and attributes according to the user's visualization goals [15,16]. Meanwhile, data for analysis of vegetation greenness changes came from Landsat-7 ETM and Landsat-8 OLI imagery at intervals of 20 years from 1999-2019. Even so, not all bands in the image are used for vegetation greenness analysis, because the Normalized Difference Vegetation Index (NDVI) algorithm only requires red and near-infrared bands (NIR) [17]. All vegetation greenness processing uses the EOS Platform and is accessed through Mozilla Firefox 75.0 (64 bit) browser.

\section{B. Data Analysis}

This research used a descriptive approach to explain the vegetation greenness changes each pixel over two different periods (see Equation 1). Vegetation greenness is obtained from NDVI values that are sensitive to chlorophyll with the algorithm as presented in Equation 2. NDVI values below 0 indicate water bodies or built-up land, values 0 - 0.2 represent built-up land with minimal vegetation, while values $0.2-0.4$ indicate mixture-vegetation areas [18]. The higher NDVI values indicate the high vegetation greenness in an area where values $>0.4$ are expressed as fully vegetated [19].

\section{LAND}

VIEWER

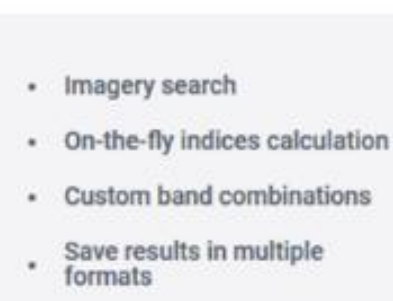

Fig. 1. EOS Platform products.

$$
\begin{aligned}
& \Delta N D V I=N V_{0(i, j)}-N V_{t}(i, j) \\
& N D V I=\frac{N I R-R e d}{N I R+R e d}
\end{aligned}
$$

Where NDVI is a vegetation greenness value, $0_{(i, j)}$ shows the pixel location in the first period with coordinates $i$ and $j, t_{(i, j)}$ shows the pixel location in the second period with coordinates $i$ and $j$, NIR is the near-infrared band, and Red is the red band.

\section{RESULT AND DISCUSSION}

EOS Platform as the cloud-based GIS vendor offers four integrated products ie. Land Viewer, EOS Processing, EOS Storage, and EOS Vision which can be accessed on the page https://platform.eos.com/platform (Figure 1). This vegetation greenness only uses three products without EOS Vision. In this analysis, it begins by uploading AOI to the Land Viewer and directs the map on research location. After that, search satellite images by entering the sensor types and instruments, observation time, and the type of scene or mosaic data that are similar to Google Earth Engine [20,21]. To reduce data usage, users can use clipping and band selection features, then save it to EOS Storage and wait for the notification to appear. If image data already exist in EOS Storage, analysis of vegetation greenness switch to EOS Processing and select NDVI workflow (see Figure 2). The results of the analysis in the two different periods will be re-stored in EOS Storage and only downloaded for offline layout - exporting data.

Analysis of vegetation greenness using the EOS Platform only downloads final data of less than $50 \mathrm{Mb}$, it appears that this cloud-based GIS can cut data downloads from before and reach 75-95 \% for each scene. At a glance from Figure 2, there is an increase in vegetation greenness in Cirebon Regency due to the legendary information that uses a relative scale - the upper limits (maximum value) and bottom (minimum value) between two images are different. But the application of Equation 1 shows the vegetation greenness in this region for twenty years as presented in Figure 3. The decrease occurs more in the western and peri-urban areas bordering the Cirebon City. This information shows that there has been a gradual change in usage towards the built-up area [22].

\section{(ㅇ) EOS Processing}

\section{EOS Storage}

\section{EOS Vision}

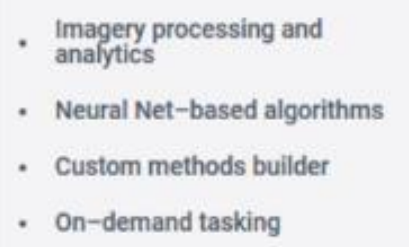

- Data Storing

- Sharing and Distributing

- Raster and Vector data preview

Format converter (coming soon)

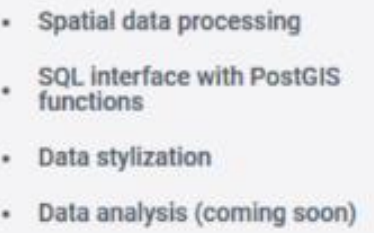

Spatial data processing SQL interface with PostGIS Data analysis (coming soon) 


\section{Step 1}

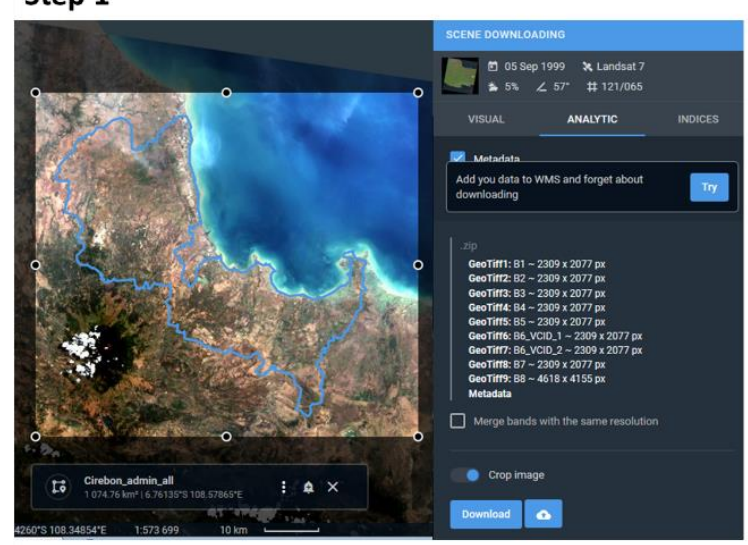

\section{Step 2}

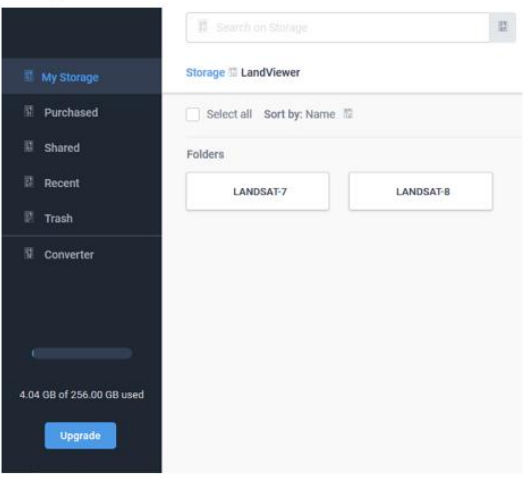

Step 3

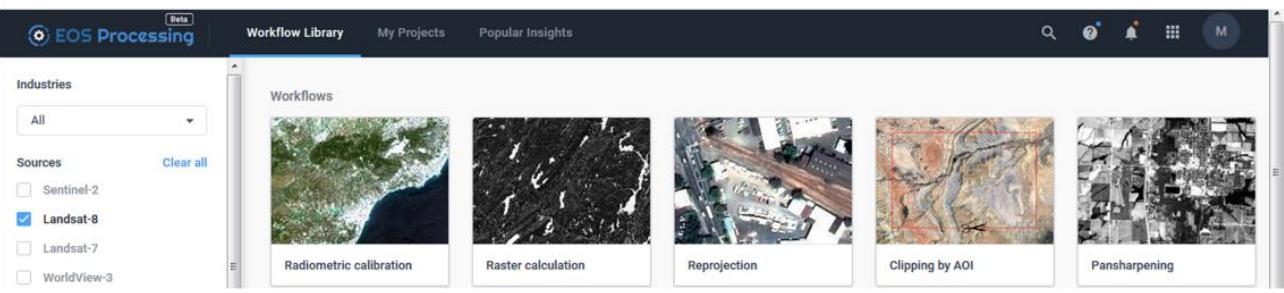

Fig. 2. Interaction between EOS Platform products in vegetation greenness analysis.

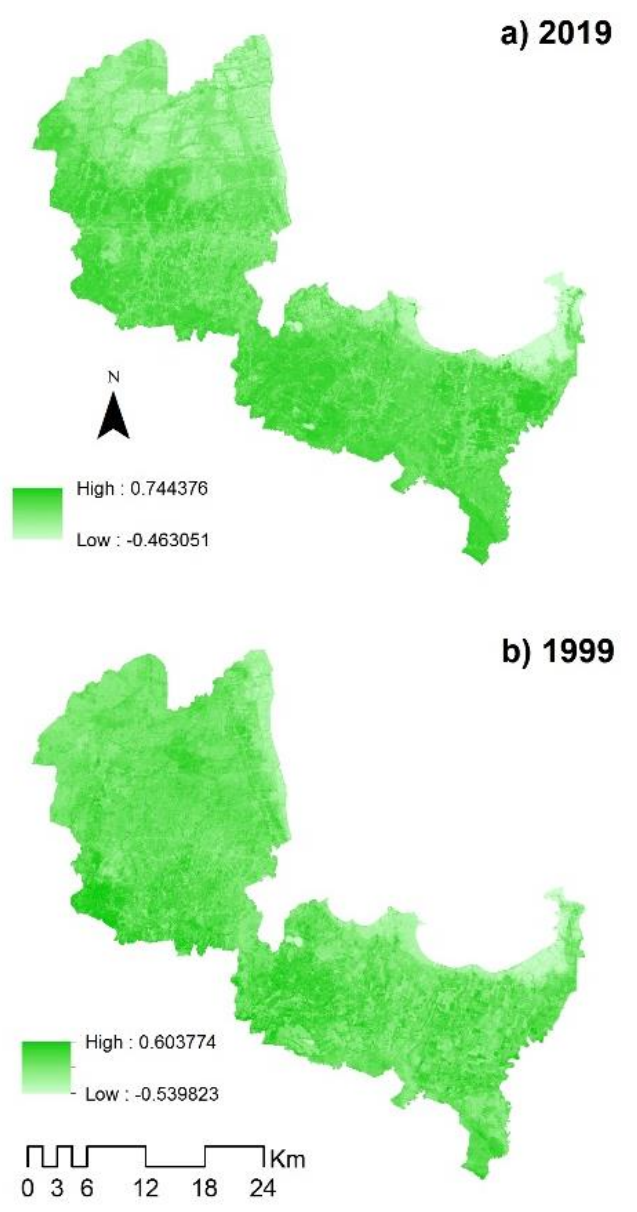

Fig. 3. Vegetation greenness from NDVI analysis on the EOS Platform.

Vegetation greenness analysis using the EOS Platform has proven to be effective as an alternative to online and cloudbased GIS image processing. This is evidenced by the results in line with other studies concerning changes in the landscape in Cirebon and surrounding areas due to the construction of settlements, industrial areas, and infrastructures such as coalfired power plants [23]. Even so, at some points on the north coast and surrounding river, it increases in vegetation greenness due to the tree-planting movement carried out by the local government and community. Besides, the dynamics of landforms such as the accretion in the coast and sedimentation on the river banks allow for an ideal habitat for vegetation.

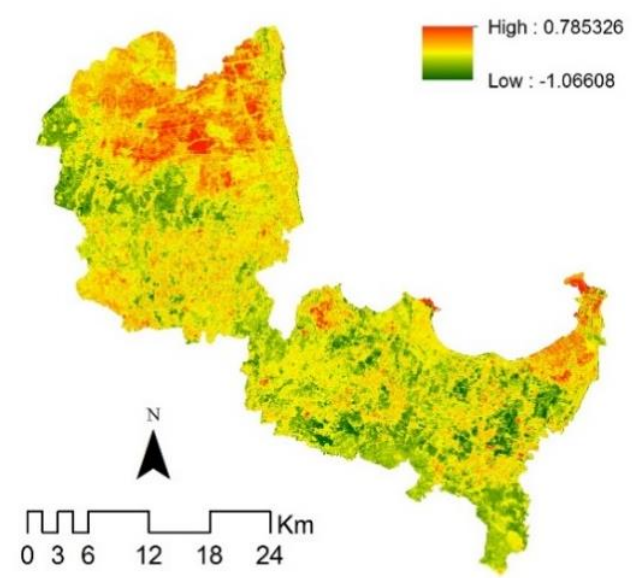

Fig. 4. Changes in vegetation greenness value. A positive value indicates a reduction and vice versa.

From this analysis, it is also known that observations of vegetation greenness can be done periodically according to the recording of satellite images every 16 days (Landsat series) or 
10 days (Sentinel-2A and Sentinel-2B) which can be processed on the EOS Platform through a browser or connecting the web map features service (WMS) on desktop GIS software. Although this feature is also provided by many geoportal pages such as OpenStreetMap (OSM), InaGeoportal (BIG), ArcGIS Geoserver, USGS, and others [24]. This integration allows EOS Platform users to display the analysis results, metadata, and download them directly on the PCs [25]. Besides, the EOS Platform has an API that can be used with programming languages.

Thus, is the processing of vegetation greenness or other algorithms on the EOS Platform without obstacles? Even though it is more user friendly than Google Earth Engine, obstacles arise not on all EOS Platform products but on EOS Storage which sometimes fails to integrate with Land Viewer and EOS Processing. This problem causes satellite images that have been selected based on AOI and certain bands to be slow stored, even though the notification in Land Viewer states that the image has been saved. Another obstacle arises in EOS Processing which is not able to do clipping by using asymmetric AOI, so it is overcome offline using GIS software on PCs ie. QGIS, SAGA, or ArcGIS. The obstacles are reasonable because EOS Processing and EOS Storage are still BETA versions and require refinement of the initial user experience until finally the full version is released [26].

\section{CONCLUSION}

EOS Platform as a cloud-based GIS has proven to be effective in analyzing the vegetation greenness in Cirebon Regency. The analysis shows a decrease in NDVI values in the western and peri-urban areas which reach 0.38 . Vegetation greenness has increased in areas rarely touched by humans or designated as green areas. From these results, it is also known that the EOS Platform can save 75-95\% on data usage and offer satellite image processing speeds. Despite having some bugs due to the BETA version of EOS Storage and EOS Processing products, this platform can be relied upon to process geospatial data on a country scale as long as it does not download more than 10 scenes or mosaic per day - for free users. Even the existence of indices features on Land Viewer products can facilitate remote sensing learning based on digital images and cloud computing. Hence, the EOS Platform needs to fix bugs for better user experience in the future in terms of integration between their products.

\section{REFERENCES}

[1] M. A. Widiawaty, Mari Mengenal Sains Informasi Geografis. Bandung: Aria Mandiri Group, 2019.

[2] M. Dede, M. A. Widiawaty, I. Setiawan, and N. Huda. (2019). Integrasi AHP dan sistem informasi geografis untuk analisis potensi kerawanan illegal fishing di Indonesia. Jurnal Sains Informasi Geografi, 2 (2), pp. 8-17.

[3] C. Doldirina. (2015). Open data and earth observations: the case of opening up access to and use of earth observation data through the global earth observation system of systems. JIPITEC, 6, pp. 73-85.

[4] H. Sajjad and P. Kumar. Future challenges and perspective of remote sensing technology: potential and future trends. In Applications and Challenges of Geospatial Technology. Basel: Springer Nature Switzerland AG, 2019.
[5] M. Jha and V. Chowdary. (2007). Challenges of using remote sensing and gis in developing nations. Hydrogeology Journal, 15, pp. 197-200.

[6] M. Dede, M. A. Widiawaty, G. P. Pramulatsih, A. Ismail, A. Ati and H. Murtianto. (2019). Integration of participatory mapping, crowdsourcing and geographic information system in flood disaster management (case study Ciledug Lor, Cirebon). Journal of Information Technology and Its Utilization, 2 (2), pp. 44-47.

[7] J. O'Brien, J. O. Wallgrün, J. Detwiler and A. Murdoch. (2020). GEOG 489: Advanced Python Programming for GIS. [Online]. Available https://www.e-education.psu.edu/geog489/node/1405.

[8] O. Mutanga and L. Kumar. (2019). Google Earth Engine applications. Remote Sensing, 11, 591.

[9] J. Rapinski, M. Bednarczyk and D. Zinkiewicz. (2019). JupyTEP ide as an online tool for earth observation data processing. Remote Sensing, 11, 1973.

[10] M. M. Ar-Rahiem, M. R. Fakhlevi and M. I. Hekmatyar, M. I. Analisis Fenomena Pulau Panas Perkotaan Kota Bandung Menggunakan Google Earth Engine. In Prosiding Seminar Nasional Penginderaan Jauh Tahun 2019. Jakarta, 2019.

[11] J. Lawhead, Learning Geospatial Analysis with Python. Birmingham: Packt Publishing Ltd., 2019.

[12] EOS. (2020). EOS Platform. [Online]. Available https://eos.com/platform/.

[13] L. Kumar and O. Mutanga. (2018). Google Earth Engine applications since inception: usage, trends, and potential. Remote Sensing, 10, 1509

[14] M. Dede, G. P. Pramulatsih, M. A. Widiawaty, Y. R. Ramadhan and A. Ati. (2019). Dinamika suhu permukaan dan kerapatan vegetasi di Kota Cirebon. Jurnal Meteorologi Klimatologi dan Geofisika, 6 (1), pp. 2331.

[15] S. Arifin. Penyajian dan visualisasi citra ortho satelit landsat produk Indonesia's National Carbon Accounting System (INCAS) dalam Google Earth. In Prosiding Seminar Nasional Teknologi Informasi dan Komunikasi. Yogyakarta, 2013.

[16] U. Upendi. (2017). Geographic information system produksi energi dan pertambangan Kabupaten Musi Banyuasin. Jurnal Nasional Teknologi dan Sistem Informasi, 3 (3), pp.360-369.

[17] W. Nurdian, M. Dede, M. A. Widiawaty, Y. R. Ramadhan and Y. Purnama. Pemanfaatan sensor Mikro DHT11-Arduino untuk monitoring suhu dan kelembaban udara. In Prosiding Seminar Nasional Tahunan Ilmu Lingkungan Universitas Padjadjaran. Bandung, 2019.

[18] J. A. Sobrino, J. C. Jiménez-Muñoz and L. Paolini. (2004). Land surface temperature retrieval from Landsat TM 5. Remote Sensing of Environment, 90 (4), pp. 434-440.

[19] B. Govaerts and N. Verhulst, The Normalized Difference Vegetation Index (NDVI) GreenSeeker ${ }^{\mathrm{TM}}$ Handheld Sensor: Toward the Integrated Evaluation of Crop Management. Mexico City: CIMMYT, 2010.

[20] J. Navarro. First experiences with Google Earth Engine. In Proceeding of 3rd International Conference on Geographical Information Systems Theory, Applications and Management (GISTAM 2017). Porto, 2017.

[21] G. Donchyts. (2019). Google Earth Engine Workshop. [Online] Available: http://www.jerico-ri.eu/download/summer\%20school\%20 $\% 20$ the \%20netherlands/Genna\%20Donchyts\%20-\%20GEE\%20Trainin g.pdf.

[22] M. A. Widiawaty, A. Ismail, M. Dede and Nurhanifah. (2020) Modeling LULC dynamic using geographic information system and Markov-CA. Geosfera Indonesia, 4: 1-15.

[23] M. Dede, M. A. Widiawaty, Nurhanifah, A. Ismail, A. R. P. Artati, A. Ati and Y. R. Ramadhan. (2020). Estimasi perubahan kualitas udara berbasis citra satelit penginderaan jauh di sekitar PLTU Cirebon. Jambura Geoscience Review, 2 (2).

[24] C. D. Michaelis and D. P. Ames. Web Feature Service (WFS) and Web Map Service (WMS). In Encyclopedia of GIS. New York: Springer, 2017.

[25] U. Gandhi. (2019). Bekerja dengan Data WMS. [Online]. Available: http://www.qgistutorials.com/id/docs/working_with_wms.html.

[26] C. K. N. C. K. Mohd and F. Shahbodin. (2015). Personalized learning environment: alpha testing, beta testing \& user acceptance test. Procedia - Social and Behavioral Sciences, 195, pp. 837-843. 